\title{
CREATING THE GROWTH POTENTIAL OF GLOBAL CITIES IN THE CONTEXT OF DIGITALIZATION
}

\begin{abstract}
The peculiarities of the development of global cities and their role in the development of the world economy are considered. The trends of economic development of global cities is analysed and the main industries towards which investments are directed are identified. It is noted that innovations play a leading role in increasing competitiveness and establishing a sustainable economic and social system. Particular attention is paid to technologies that determine the sectoral and territorial structure of cities, including artificial intelligence, the Internet of Things, blockchain and 5G. The digital strategies of global cities are studied, which, despite different structure and priorities, set general principles for the development of the information technology and telecommunications sector and the implementation of its results in economic and social processes (government, infrastructure, technology parks, etc.). It is established that global cities should adhere to the developed strategy of digital transformation in determining the digital priorities. It is substantiated that the development of digital infrastructure is the basis for the creation of growth potential of global cities.
\end{abstract}

(C) Larysa Sarkisian, 2020.

Sarkisian Larysa, Candidate of Economic Sciences, Associate Professor at the Department of World Economy, Kyiv National University of Trade and Economics, Ukraine, ORCID: 0000-0003-3030-5000, Email: sarkisianlg@gmail.com. 


\section{Key words:}

Global cities, investment climate, digitalization, information technologies and telecommunications, strategic planning, development priorities.

JEL: F01, F20, F63.

\section{Problem statement}

In the context of growing global challenges caused by slowing economic growth and a number of macroeconomic factors, the role of global cities as innovation and investment drivers is becoming vital. Balancing the economic system requires the inclusion of the city in the network of global financial, sectoral, academic and information networks. Addressing the multifaceted issues of urban planning and development requires sound strategic approaches and an appropriate support system. Thus, research is needed on issues related to the economic potential and investment attractiveness of global cities, as well as technological challenges and priority areas for their development in the context of digitalization.

\section{Analysis of recent research and publications}

Scientists who have made a significant contribution to the development of the concept of global cities as drivers of economic growth, the role of investment in the urban technology sector in the context of digitalization include R. Kramarenko, J. Trujillo, J. Parilla, N. Nimchenko, R. Belderbos, H. S. Du, A. Slangen, S. Sassen, A. Townsend, S. Lorimer.

While we acknowledge the work of Ukrainian and foreign researchers in the development of basic principles and approaches to the concept of global cities, we note that a number of topical issues related to digital strategy planning still require in-depth research, especially in the context of rapid technology development and their impact on all key economic areas of city systems. 


\section{Aim of the article}

The main purpose of this work is to determine the basic principles of development that affect the creation of the global cities' potential in the context of digitalization.

\section{Main findings}

The economy of cities and regions is undergoing significant transformations, due to both the impact of changes in population growth rates caused by rapid industrialization, and changes in sectoral structure caused by scientific and technological progress and technological revolutions.

According to the United Nations (UN), in 2018, approximately $55.3 \%$ of the world's population lived in urban settlements, and by 2030 , urban areas are projected to be home to up to $60 \%$ of people worldwide, and one in three people will live in cities with at least half a million inhabitants (United Nations 2018). Accordingly, in urban settlements a class of persons is formed whose identity differs in its worldview and positioning from other people living within the respective countries. This significantly affects economic behaviour and creates the need to define a different system of incentives.

The economic behaviour of cities determines their positioning in the global network of urban development and, to a large extent, influences the forecasts for their future (Table 1). The greatest growth of economic and social potential of cities is associated with high rates of urbanization in developing countries, where rapid growth of economic indicators (especially GDP) is expected, namely: India, Bangladesh, China, Indonesia, Philippines.

Such cities have a rather complex sectoral structure of the economy, the technological level of their industries is much higher than the national average, and they also have a certain «magnetism» with unprecedented opportunities for round-the-clock production processes, productivity growth, intensification of production, introduction of innovations and unlimited prospects of harmonious personal development (Kramarenko 2016, p. 82). This determines the growing prospects for urban expansion and cities' functioning as separate components of the global system, capable of forming the current and future agenda.

The global economic system defines new roles of the main actors involved in the process of its formation. Cities have always played a leading role in the establishment of leading countries in socio-economic development. Modern global cities are becoming sufficiently independent players, whose policies can make adjustments to the established order of domestic and foreign, especially economic, policies. 
Table 1

GDP growth of global cities (forecast - 2035)

\begin{tabular}{|c|l|l|c|}
\hline Ranking & \multicolumn{1}{|c|}{ City } & \multicolumn{1}{c|}{ Country } & Growth rate, $\%$ \\
\hline 1 & Bengaluru & India & 8,5 \\
\hline 2 & Dhaka & Bangladesh & 7,6 \\
\hline 3 & Mumbai & India & 6,6 \\
\hline 4 & Delhi & India & 6,5 \\
\hline 5 & Shenzhen & China & 5,3 \\
\hline 6 & Jakarta & Indonesia & 5,2 \\
\hline 7 & Manila & Philippines & 5,2 \\
\hline 8 & Tianjin & China & 5,1 \\
\hline 9 & Shanghai & China & 5,0 \\
\hline 10 & Chongqing & China & 4,9 \\
\hline
\end{tabular}

Source: compiled by the author based on (Ghosh 2019).

Urbanization, global integration and technological change are the main forces that are changing the modern international economy (Trujillo \& Parilla 2016, p. 7). These drivers are the cornerstones of the global cities' competitiveness; enable their involvement in global economic, social, environmental and cultural processes, and receipt of the applicable benefits.

The development of global cities and the creation of an interconnected network of cities operating in accordance with the same financial, investment, innovation and cultural systems approaches determines the globalization trends. The main task of global cities is to increase productivity by promoting technological and innovative activity of business and academic communities.

A global city is a manifestation of an international network of strategic platforms. No fixed list of global cities falls under the modern notion of a global city, as they are made up by countries that refuse to regulate their economies and privatize the public sector (in order to offer something to international investors). Different criteria are used to distinguish the construct of a global city and a city in general. Each city has its own materiality, politics, sociality, its own pedigree. The development of the functions of the global city, the endogenous nature of the trends and the conditionality of economic globalization in urban space are a strategic but not a comprehensive phenomenon. An important methodological consequence is that one can actually study the functions of a global city without studying the city as a whole (Nimchenko 2014).

The role and functions of global cities are determined by their importance and impact on the economic development of both individual regions and the 
world economy as a whole. It is estimated that cities produce 34 trillion US dollars, or more than $50 \%$ of world GDP, and, according to forecasts, their share could reach 65 trillion USD by 2025 (Dragicevic et al. 2013, p. 46).

According to the above, global cities are a function of a global network of strategic planes with complex specialization and content. Researchers group global cities into so-called megaregions, which combine a number of geographically close areas with similar characteristics into a single entity. Megaregions unite cities whose total population ranges from 50 to 20 million people, gross output per capita is between $\$ 76,000$ and $\$ 32,000$ according to the data of 2018 (Table 2).

Table 2

The role of megaregions in the development of the global economy, 2018

\begin{tabular}{|c|c|c|c|c|c|}
\hline $\begin{array}{l}\text { Megare- } \\
\text { gion }\end{array}$ & Cities & $\begin{array}{c}\text { Conti- } \\
\text { nent }\end{array}$ & $\begin{array}{l}\text { Popula- } \\
\text { tion, mil- } \\
\text { lion }\end{array}$ & $\begin{array}{l}\text { Gross out- } \\
\text { put (GO), } \\
\text { billion USD }\end{array}$ & $\begin{array}{l}\text { GO per } \\
\text { capita, } \\
\text { USD }\end{array}$ \\
\hline $\begin{array}{l}\text { 1. Bos- } \\
\text { Wash }\end{array}$ & $\begin{array}{c}\text { New York, } \\
\text { Washington DC, } \\
\text { Boston }\end{array}$ & $\begin{array}{c}\text { North } \\
\text { America }\end{array}$ & 47.6 & 3,650 & 76,681 \\
\hline $\begin{array}{l}\text { 2. Par-Am- } \\
\text { Mun }\end{array}$ & $\begin{array}{l}\text { Paris, Amster- } \\
\text { dam, Brussels, } \\
\text { Munich }\end{array}$ & Europe & 43.5 & 2,505 & 57,586 \\
\hline 3. Chi-Pitts & $\begin{array}{l}\text { Chicago, De- } \\
\text { troit, Cleveland, } \\
\text { Pittsburgh }\end{array}$ & $\begin{array}{c}\text { North } \\
\text { America }\end{array}$ & 32.9 & 2,130 & 64,742 \\
\hline $\begin{array}{l}\text { 4. Greater } \\
\text { Tokyo }\end{array}$ & Tokyo & Asia & 39.1 & 1,800 & 46,036 \\
\hline 5. SoCal & $\begin{array}{c}\text { Los Angeles, } \\
\text { San Diego }\end{array}$ & $\begin{array}{c}\text { North } \\
\text { America }\end{array}$ & 22 & 1,424 & 64,727 \\
\hline $\begin{array}{l}\text { 6. Seoul- } \\
\text { San }\end{array}$ & Seoul, Busan & Asia & 35.5 & 1,325 & 37,324 \\
\hline $\begin{array}{l}\text { 7. Texas } \\
\text { Triangle }\end{array}$ & $\begin{array}{l}\text { Dallas, Hous- } \\
\text { ton, San Anto- } \\
\text { nio, Austin }\end{array}$ & $\begin{array}{c}\text { North } \\
\text { America }\end{array}$ & 18.4 & 1,227 & 66,685 \\
\hline 8. Beijing & Beijing, Tianjin & Asia & 37.4 & 1,226 & 32,781 \\
\hline $\begin{array}{l}\text { 9. Lon-Leed- } \\
\text { Chester }\end{array}$ & $\begin{array}{c}\text { London, Leeds, } \\
\text { Manchester }\end{array}$ & Europe & 22.6 & 1,177 & 52,080 \\
\hline $\begin{array}{l}\text { 10. Hong- } \\
\text { Shen }\end{array}$ & $\begin{array}{l}\text { Hong Kong, } \\
\text { Shenzhen }\end{array}$ & Asia & 19.5 & 1,043 & 53,487 \\
\hline Total & & & 602.2 & 28,135 & 46,720 \\
\hline
\end{tabular}

Source: (Ghosh 2019). 

in the Context of Digitalization

The highest position in the ranking is occupied by the mega-region BosWash, which is located in the United States, and includes cities - financial, industrial, technological, scientific, political centres - New York, Washington and Boston. The population of this region is $\mathbf{4 7 . 6}$ million people with gross output per capita of 76.681 US dollars. This is well above the number of people living in the other North American megaregion of NoCal, which includes the cities of San Francisco and San Jose, with 10.8 million people, but a much higher rate of gross output per capita of $\$ 85.648$. The difference is primarily due to the technological specialization of the NoCal region and the location of Silicon Valley, which gives impetus to the development of the largest technology companies in the region and the world.

Other significant North American megaregions are the Chi-Pitts (Chicago, Detroit, Cleveland, Pittsburgh) - \$64,742 GO per capita; SoCal (Los Angeles, San Diego) - \$64,727 GO per capita; Texas Triangle (Dallas, Houston, San Antonio, Austin) $-\$ 66,685$ GO per capita. Thus, the US megaregions and global cities that are part of them are leaders in terms of both gross output and per capita indicators and, accordingly, determine the direction of the world economy in the financial, technological, industrial and political arenas. Only two megaregions are located in Europe: Par-Am-Mun (Paris, Amsterdam, Brussels, Munich) and Lon-Lead-Chester (London, Leeds, Manchester) with GO per capita of 57.586 USD and 52.080 USD, respectively. The region of rapid urbanization Southeast Asia - is increasing its industrial, technological and political capacity every year and adding new alternatives to the development of the global economy. The top ten also includes four Asian megaregions, one in Japan, one in South Korea and two in China. The highest GO per capita is in the Greater Tokyo megaregion (Tokyo agglomeration) - 46.036 USD, the lowest - in Beijing (Beijing, Tianjin) with 32.781 USD.

Innovations are drivers of economic growth of global cities; they create new opportunities for the inclusion of local scientific and business environment into the global network of new knowledge and technologies. According to the index of urban innovation in 2019, among the most highly ranked were such cities as New York, Tokyo, London, Los Angeles, Singapore, Paris, Chicago, Boston, San Francisco - San Jose, and Toronto (Wood 2019).

The growth of global cities as centres of innovation creates a big demand for improving the efficiency of their operation and development. Integration into the global economic space and their incorporation into the decision-making system determines the direction of urban growth. Global cities determine new tasks at all levels of government, from the lowest to the highest (from meso to mega level).

The main producers of innovations are multinational companies (MNCs), whose competitiveness is largely determined by their ability to create new products and services. This facilitates the inclusion of global cities into the management system of global production networks coordinated by the MNCs. Localiza- 
tion of international business promotes investment and the creation of growth hubs. The knowledge-intensive sectors that require significant human and social capital in creating value added goods and services are the most investmentattractive areas. On average, the percentage of investments in the global cities out of the total investment in the country is $10 \%$ (Table 3 ).

Table 3

Volumes of investments in some global cities (2008-2012)

\begin{tabular}{|c|c|c|c|c|c|}
\hline Countries & $\begin{array}{c}\text { Number of } \\
\text { investments, } \\
\text { total }\end{array}$ & $\begin{array}{c}\% \text { of } \\
\text { in- } \\
\text { vestme } \\
\text { nts }\end{array}$ & $\begin{array}{c}\text { Number of in- } \\
\text { vestments into } \\
\text { global cities }\end{array}$ & $\begin{array}{c}\% \text { of in- } \\
\text { vestments } \\
\text { into global } \\
\text { cities }\end{array}$ & $\begin{array}{c}\text { Global cities } \\
\text { (number of in- } \\
\text { vestments) }\end{array}$ \\
\hline China & 1,595 & 13.6 & 540 & 33.9 & $\begin{array}{l}\text { Shanghai (299), } \\
\text { Beijing (146), } \\
\text { Guangzhou (70), } \\
\text { Shenzhen (25) }\end{array}$ \\
\hline India & 1,034 & 8.8 & 323 & 31.2 & $\begin{array}{l}\text { Bengaluru (125), } \\
\text { Mumbai (81), } \\
\text { New Delhi (59), } \\
\text { Chennai (47) }\end{array}$ \\
\hline & 1,318 & 11.2 & 247 & 18.7 & $\begin{array}{l}\text { New York (39), } \\
\text { Chicago (28), } \\
\text { Miami (28), } \\
\text { Houston (25) }\end{array}$ \\
\hline
\end{tabular}

Source: (Belderbos et al 2020)

The largest amount of investment was directed to Chinese global cities such as Shanghai, Beijing, Guangzhou and Shenzhen. Municipal authorities of these and other cities paid considerable attention to strategic priorities of development, creation of the corresponding infrastructure, increase of educational and scientific levels.

For example, the following measures contributed to enhancing Shanghai's investment strategy as an international financial, trade, logistics, and economic hub:

- Shanghai Free Trade Area, which was first established in mainland China in 2013. 
- Access to finance through regulatory initiatives, tax incentives, capital funding incentive programmes and others.

- High-tech parks used to capitalize areas that are subject to constraints (e.g. the healthcare sector and the banking system).

- Identification of specialized functional areas - for innovation, business, leisure, gateway, production and delivery of goods - to attract talent and promote inclusive economic development (Global Cities Business Alliance 2016, p.11).

Table 4

Main FDI sectors in global cities (2004-2018)

\begin{tabular}{|c|c|c|c|c|c|c|c|c|c|}
\hline \multirow[t]{2}{*}{ No } & \multicolumn{3}{|c|}{$2004-2008$} & \multicolumn{3}{|c|}{$2009-2013$} & \multicolumn{3}{|c|}{$2014-2018$} \\
\hline & Sector & FDI & $\%$ & Sector & FDI & $\%$ & Sector & FDI & $\%$ \\
\hline 1 & $\begin{array}{l}\text { Software } \\
\text { and IT } \\
\text { service }\end{array}$ & 1273 & 33 & $\begin{array}{l}\text { Software } \\
\text { and IT } \\
\text { service }\end{array}$ & 1091 & 27 & $\begin{array}{l}\text { Software } \\
\text { and IT } \\
\text { service }\end{array}$ & 1855 & 35 \\
\hline 2 & $\begin{array}{l}\text { Communi- } \\
\text { cations }\end{array}$ & 388 & 10 & $\begin{array}{l}\text { Communi- } \\
\text { cations }\end{array}$ & 369 & 9 & $\begin{array}{l}\text { Communi- } \\
\text { cations }\end{array}$ & 450 & 9 \\
\hline 3 & $\begin{array}{l}\text { Semicon- } \\
\text { ductors }\end{array}$ & 319 & 8 & Chemicals & 302 & 4 & Chemicals & 301 & 6 \\
\hline 4 & $\begin{array}{l}\text { Pharma- } \\
\text { ceutical }\end{array}$ & 313 & 8 & $\begin{array}{l}\text { Industrial } \\
\text { Equipment }\end{array}$ & 236 & 5 & $\begin{array}{l}\text { Business } \\
\text { Services }\end{array}$ & 294 & 6 \\
\hline 5 & $\begin{array}{c}\text { Industrial } \\
\text { Equipment }\end{array}$ & 175 & 5 & $\begin{array}{c}\text { Pharma- } \\
\text { ceutical }\end{array}$ & 228 & 8 & $\begin{array}{l}\text { Industrial } \\
\text { Equipment }\end{array}$ & 293 & 6 \\
\hline 6 & Chemicals & 172 & 4 & $\begin{array}{l}\text { Business } \\
\text { Services }\end{array}$ & 202 & 4 & $\begin{array}{l}\text { Automo- } \\
\text { tive Com- } \\
\text { ponents }\end{array}$ & 249 & 5 \\
\hline 7 & $\begin{array}{l}\text { Automo- } \\
\text { tive Com- } \\
\text { ponents }\end{array}$ & 164 & 4 & $\begin{array}{l}\text { Automo- } \\
\text { tive Com- } \\
\text { ponents }\end{array}$ & 175 & 4 & $\begin{array}{l}\text { Pharma- } \\
\text { ceutical }\end{array}$ & 203 & 4 \\
\hline 8 & $\begin{array}{l}\text { Electronic } \\
\text { Compo- } \\
\text { nents }\end{array}$ & 114 & 3 & $\begin{array}{c}\text { Electronic } \\
\text { Compo- } \\
\text { nents }\end{array}$ & 173 & 3 & $\begin{array}{l}\text { Food and } \\
\text { Tobacco }\end{array}$ & 181 & 3 \\
\hline 9 & $\begin{array}{l}\text { Biotech- } \\
\text { nology }\end{array}$ & 109 & 3 & $\begin{array}{l}\text { Semicon- } \\
\text { ductors }\end{array}$ & 150 & 8 & $\begin{array}{c}\text { Electronic } \\
\text { Compo- } \\
\text { nents }\end{array}$ & 159 & 3 \\
\hline 10 & $\begin{array}{l}\text { Automo- } \\
\text { tive OEM }\end{array}$ & 103 & 3 & $\begin{array}{l}\text { Food and } \\
\text { Tobacco }\end{array}$ & 128 & 3 & $\begin{array}{l}\text { Automo- } \\
\text { tive OEM }\end{array}$ & 158 & 3 \\
\hline
\end{tabular}

Source: compiled by the author based on (Greater Paris Investment Agency 2019) 
The sustainability of economic development is ensured by creating a favourable investment climate, establishing an active dialogue with investors, and identifying priority areas for investment. According to the data, the main sectors towards which foreign direct investment (FDI) was directed from 2004 to 2018 were: software and IT services (on average at 30\%), communications (on average at $9 \%$ ), chemical industry (on average at the level of $5 \%$ ) (Table 3 ).

Accordingly, economic globalization and digitalization create space for cities that focus on de-territorialized cross-border networks and areas with a high concentration of resources. Under these conditions, much of what we experience and present as local, is a microenvironment from the global network, with nonlocal dynamics and / or localization of global processes (Sassen 2010).

The concentration of resources in the software and IT services sector has a significant impact on not only the industry in this sector, but also on all others, including such traditional sectors as agro-industrial, construction, chemical and others. This determines the importance of creating appropriate infrastructure (universities, business incubators, technology parks, venture funds, technical means) for the development of the sector. The expansion of the sector largely determines competitiveness and growth forecasts in all global cities, regardless of location. After all, the level of development of this sector determines the possibility of inclusion in global financial, trade, transport, and socio-cultural networks, which are associated with the key characteristics of the current stage of development of the global economy.

The increasing the investment attractiveness of the software and IT services sector is primarily caused by the growing number of people connected to digital devices that use different types of programs and applications. However, the main consumers of the sector's products are businesses, whose data use necessitates an increase in the number of sensors and devices in industrial, commercial, infrastructure, health, transport and many other areas.

Emerging technologies in the software and IT services sector are artificial intelligence (AI), blockchain, Internet of Things and 5G. Examples of incorporating technology products into business processes include the use of blockchain technology in the supply network by Walmart, the creation of contactless retail spaces by Amazon, automation and robotization of production processes by Tesla and many others. In 2019, the total value of emerging technologies amounted to 168.6 billion USD, Internet of Things and artificial intelligence in the lead. According to forecasts, in 2029 the total cost of technology will increase approximately 5 times, and will amount to 573.8 billion USD, with a significant share of $5 G$ technology and blockchain (Fig. 1).

The study was conducted on the basis of data from 60 largest cities in the world and formed a ranking of 10 digital capitals, namely: New York; Los Angeles; Tokyo; San Francisco; Singapore; London; Chicago; Toronto; Paris; Hong Kong. The growth of the digital economy will allow these cities to adapt to fluctuations in global economic cycles more effectively, primarily through further diversification of the economic system and increase in innovation, investment and socio-cultural attractiveness. 
Figure 1

Aggregate value of emerging technologies in global cities, billion USD

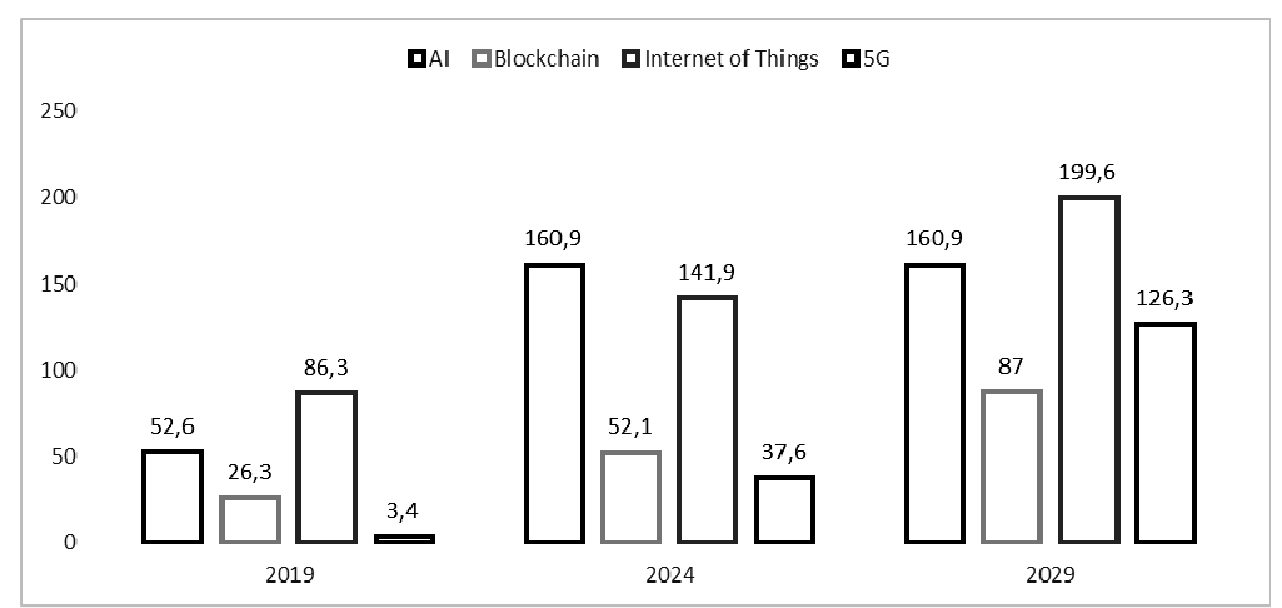

Source: created by the author based on (PR Newswire 2019).

Analysis of venture capital investments by companies in the development of artificial intelligence technologies in global cities allows us to determine that the increase in investment is associated with an increase in the number of technology companies (including start-ups) and the introduction of artificial intelligence into management optimization, product promotion, banking services, production, and in the field of health care (table 5).

It should be noted that an increasing number of companies, from ecommerce to insurance to consulting services, are using artificial intelligence technology. For example, the largest employers in London that work with, among other things, artificial intelligence technologies are: Facebook, Twitter, UCL, Amazon.com, BenevolentAI, Farfetch, QuantaBlack, PredictX, WorldReit, GResearch, Deloitte, Expedia, AIG, Babylon (Digital Intelligence 2018).

Accordingly, the digitalization of technological processes and changes in product life cycles affect the competitiveness of cities and their place in the global hierarchy, which requires a revision of traditional approaches to strategic planning. Global cities have already gained sufficient experience in creating and implementing digital strategies, the first of which was formulated in Hong Kong in 1998 - «Hong Kong - a digital city in the 21st century», and has been revised several times (Table 6). 
Table 5

Venture capital in the development of artificial intelligence technologies, 2013-2018, million pounds

\begin{tabular}{|c|l|c|c|c|c|c|c|c|}
\hline No & $\begin{array}{l}\text { Cities/ } \\
\text { years }\end{array}$ & 2013 & 2014 & 2015 & 2016 & 2017 & 2018 & Total \\
\hline 1 & $\begin{array}{l}\text { San- } \\
\text { Francisco }\end{array}$ & 418.08 & $\begin{array}{c}1.83 \\
\text { billion }\end{array}$ & $\begin{array}{c}2.07 \\
\text { billion }\end{array}$ & $\begin{array}{c}4.46 \\
\text { billion }\end{array}$ & 806.03 & $\begin{array}{c}1.84 \\
\text { billion }\end{array}$ & $\begin{array}{c}11.44 \\
\text { billion }\end{array}$ \\
\hline 2 & Beijing & 11.66 & 53.75 & 197.32 & 599.56 & $\begin{array}{c}1.63 \\
\text { billion }\end{array}$ & $\begin{array}{c}1.07 \\
\text { billion }\end{array}$ & $\begin{array}{c}3.57 \\
\text { billion }\end{array}$ \\
\hline 3 & New York & 79.43 & 165.62 & 318.28 & 667.51 & 593.85 & $\begin{array}{c}1.2 \text { bil- } \\
\text { lion }\end{array}$ & $\begin{array}{c}3.05 \\
\text { billion }\end{array}$ \\
\hline 4 & Shanghai & - & 1.28 & 400.93 & 16.10 & $\begin{array}{c}1.6 \\
\text { billion }\end{array}$ & 453.61 & $\begin{array}{c}2.47 \\
\text { billion }\end{array}$ \\
\hline 5 & London & 9.85 & 41.16 & 67.04 & 166.04 & 228.97 & 326.90 & 839.96 \\
\hline 6 & Paris & 1.92 & 2.83 & 23.49 & 61.49 & 99.45 & 132.40 & 321.48 \\
\hline 7 & Singapore & 13.76 & 13.89 & 70.92 & 55.59 & 106.52 & 30.81 & 291.49 \\
\hline 8 & Tel-Aviv & 14.80 & 17.12 & 5.49 & 39.04 & 112.25 & 89.01 & 277.71 \\
\hline 9 & Berlin & 7.09 & 0.79 & 23.60 & 17.41 & 17.67 & 21.06 & 87.62 \\
\hline 10 & Bengaluru & 1.31 & 32.29 & 45.75 & 1.96 & 36.71 & 18.65 & 136.67 \\
\hline
\end{tabular}

Source: (Digital Intelligence 2018).

In the first stages of development of digitization strategies of global cities, the key areas were identified: e-government, promotion of the IT sector, citizen involvement in decision-making, open data, development of IT infrastructure, Internet access, development of IT skills, urban infrastructure. In the second stage, the following priorities were identified: expanding the city's ties with the academic community, emergency services, sensor network, government portals, progress assessment, export solutions, platforms for cloud technologies, tourism development, energy efficiency (Townsend \& Lorimer 2015).

Creating an appropriate digital infrastructure (for example, a high-speed broadband network), expanding the quantity and quality of digital services and improving the urban management system are the basis of most digital strategies and contribute to the expansion of investment activities.

For example, Seoul, among other global cities, in order to develop the digital sector, increase the investment attractiveness of the city, increase the number of technology companies, identified the direction of the Smart Seoul Strategy diginomics and created the following priorities: 
Table 6

Digital strategies of global cities

\begin{tabular}{|c|l|l|}
\hline No & \multicolumn{1}{|c|}{ City } & \multicolumn{1}{|c|}{ Strategic documents } \\
\hline 1 & New York & $\begin{array}{l}\text { Road Map for the Digital City: Achieving New York City's Digi- } \\
\text { tal Future (2011) New York City's Digital Roadmap: Progress } \\
\text { and Innovation (2012) New York City's Digital Leadership: } \\
\text { 2013 Roadmap (2013, updated 2017) }\end{array}$ \\
\hline 2 & Chicago & The City of Chicago Technology Plan (2013) \\
\hline 3 & London & $\begin{array}{l}\text { Smart London Plan (2013), Smarter London Together Road- } \\
\text { map (2018), Digital Skills Strategy (2018) }\end{array}$ \\
\hline 4 & Barcelona & $\begin{array}{l}\text { Barcelona Smart City Vision (2012), Barcelona Digital City } \\
(2015-2019)\end{array}$ \\
\hline 5 & $\begin{array}{l}\text { San- } \\
\text { Francisco }\end{array}$ & $\begin{array}{l}\text { Information \& Communication Technology Plan }(2013,2015), \\
\text { Digital Equity Strategic Plan (2019-2020) }\end{array}$ \\
\hline 6 & Hong Kong & $\begin{array}{l}\text { Hong Kong Digital 21 Strategy (1998, 2001, 2004, 2008, } \\
\left.2014^{*}\right), \text { Hong Kong Smart City Blueprint (2017) }\end{array}$ \\
\hline 7 & Singapore & Digital Government Blueprint (2018) \\
\hline 8 & Seoul & Smart Seoul Strategy (2015), Global Digital Seoul 2020 (2015) \\
\hline
\end{tabular}

Source: compiled by the author based on (Townsend \& Lorimer 2015; Mayor's Office of Media and Entertainment and NYC Digital 2017; City and County of San Francisco 2018; Adjuntament de Barcelona 2015; Innovation and Technology Bureau 2017; Greater London Authority 2018; Smart Nation 2018; Seoul Metropolitan Government 2015)

1) Active support for the creation of start-ups (goal - support for small and medium technology companies):

- Creation and management of a business incubator for artificial intelligence development;

- Creation of Gyaepo digital innovation park;

- Opening and managing the Seoul App business centre;

- Creating a support system for the financial and technology sectors;

2) Creating an integrated platform for the digital economy:

- Creation and management of Seoul Digital Foundation;

3) Digitization of industries to increase value and competitiveness:

- Supporting artificial intelligence technologies to accelerate industrial development in Green Valley industrial park (Seoul Metropolitan Government 2015). 
In order to implement the digitalization strategy effectively, each city has created or allocated a special department in the city government, which plans in detail and implements each item of the strategic document. For example, in New York, the Department of Information Technology and Telecommunications is in charge, in Seoul, the Smart Policy Bureau, in Hong Kong, the Information Office, and so on.

In order to establish effective cooperation between city governments and the business community, it is advised to cooperate in the following areas:

- Smart growth - introduction of a system of long-term strategic planning to stimulate growth with clear goals, a system of public and private investment, support for entrepreneurship with an appropriate system of regulation and incentives;

- Doing more with less - increasing efficiency by engaging business expertise, technology and data with the development of public-private partnerships;

- Winning support for change - creating a long-term vision based on sustainable interaction between the city and business, with the involvement of stakeholders with quantitative goals and a performance management system (Global Cities Business Alliance 2016, p. 6).

Thus, the city, as an independent player in the global economy, has significantly expanded its geographical and economic boundaries over the last centuries of civilization, becoming a growth point and decision-making centre. Numerous challenges and imbalances that arise during urbanization are transformed into advantages thanks to the rapid response of municipal authorities to the main triggers. Powerful scientific and educational complexes, investmentattractive industries, extensive transport and information-communication infrastructure and an appropriate management system have allowed global cities to accelerate the diffusion of innovations and get the most out of them.

\section{Conclusions}

Global economy's growing imbalances require its major players, global cities, to reconsider the traditional conditions for the creation of competitive advantages and to include digital strategies in the agenda as a prerequisite for balanced growth. Strategies create a self-sustaining mechanism that can respond to challenges through an improved and more effective governance system and incentives for economic and investment activity by increasing the number of decision-making centres, prioritizing the development of academic and business communities, increasing cooperation and strengthening links between key participants through measures to increase mobility. Further research is needed on effective areas of strategic planning, the impact of shocks of varying degrees on socio-economic development, the role of key stakeholders in the further digital transformation of cities. 


\section{References}

1. Adjuntament de Barcelona. (2015). Barcelona Digital City. Retrieved from: https://ajuntament.barcelona.cat/digital/en/digital-transformation

2. Belderbos, R., Du, H. S., Slangen, A. (2020). When do firms choose global cities as foreign investment locations within countries? The roles of contextual distance, knowledge intensity, and target-country experience. Journal of World Business, Vol. 55, Issue 1, Retrieved from: https://www.sciencedirect.com/ science/article/pii/S1090951618306473

3. City and County of San Francisco. (2018). San Francisco City Digital equity Strategic Plan 2019-2024. Retrieved from: https://sfmohcd.org/sites/default/ files/SF_Digital_Equity_Strategic_Plan_2019.pdf

4. Digital Intelligence. (2018). Top 10 European cities for Al development. Retrieved from: http://www.digitalstrategyconsulting.com/online-advertising/ online-advertising-research-tips-and-news-for-marketers/top-10-europeancities-for-ai-development/16948/

5. Dragicevic, N., Zon, N., Gold, J., Johal, S. (2013). Future State 2030: The Global Megatrends Shaping Governments. KPMG International. Retrieved from: https://assets.kpmg/content/dam/kpmg/pdf/2014/09/Future_State_2030_UA_v3.p df

6. Ghosh I. (2019). These will be the most important cities by 2035. World Economic Forum. Retrieved from: https://www.weforum.org/agenda/2019/10/ cities-in-2035/

7. Ghosh I. (2019). The Megaregions Driving the Global Economy. Visual Capitalist. Retrieved from: https://www.visualcapitalist.com/ranked-the-megaregionsdriving-the-global-economy/

8. Global Cities Business Alliance. (2016). How cities and business can for work together for growth. Discussion paper. Retrieved from: https://www.pwc.com/gx/en/psrc/pdf/gcba-cities-business-growth.pdf

9. Greater London Authority. (2018). Smarter London Together Roadmap. Retrieved from: https://www.london.gov.uk/sites/default/files/smarter_london_ together_v1.65_-_published.pdf

10. Greater Paris Investment Agency. (2019). Global cities investment monitor 2019 / New ranking trends and criteria. Retrieved from: https://gp-investmentagency.com/wp-content/uploads/2019/06/GlobalCitiesInvestmentMonitor2019 web-compressed.pdf

11. Innovation and Technology Bureau. (2017). Hong Kong Smart City Blueprint. Retrieved from: https://www.smartcity.gov.hk/doc/HongKongSmartCityBlueprint (EN).pdf 
12. Kramarenko R. (2016). Capital metropolitan cities in the global economic system: development and competitiveness factors: Doctor's Dissertation. Kyiv National Economic University named after Vadym Hetman. Kyiv, 400 p.

13. Mayor's Office of Media and Entertainment and NYC Digital. (2017). New York City's Digital Leadership: 2017 Roadmap. Retrieved from: http://nycroadmap.us

14. Nimchenko N. (2014). Methodical aspects of the global city concept. Herald of the Dnepropetrovsk National University, Series 'Economics', Vol. 22, Issue 8(2), pp. 197-202, Retrieved from: http://nbuv.gov.ua/UJRN/vdumov_2014_ $22 \_8 \% 282 \% 29 \_32$

15. PR Newswire. (2019). Global Digital Capitals Index: Al Tops Emerging Technologies List Set to Inject Billions into the World Economy. Retrieved from: https://www.prnewswire.com/news-releases/global-digital-capitals-index-aitops-emerging-technologies-list-set-to-inject-billions-into-the-world-economy300955188.html

16. Sassen, S. (2010). Reading the City in a Global Digital Age: The Limits of Topographic Representation. Procedia - Social and Behavioral Sciences, Vol. 2, Issue 5, pp. 7030-7041, Retrieved from: https://www.sciencedirect.com/ science/article/pii/S1877042810011912

17. Seoul Metropolitan Government. (2015). Global Digital Seoul 2020. Retrieved from: https://digital.seoul.go.kr/eng/digital-2020/vision-mission

18. Smart Nation. (2018). Digital Government Blueprint. Retrieved from: https://www.smartnation.sg/docs/default-source/default-document-library/ dgb_booklet_june2018.pdf

19. Townsend, A., Lorimer, S. (2015). Digital master planning: an emerging strategic practice in global cities. NYU Marron Institute of Urban Management. Retrieved from: https://marroninstitute.nyu.edu/uploads/content/Working_ Paper_25_Digital_Master_Planning.pdf

20. Trujillo, J. L., Parilla, J. (2016). Redefining Global Cities: The Seven Types of Global Metro Economies. Brookings Institution. Retrieved from: https://www.brookings.edu/ wp-content/uploads/2016/09/metro_20160928_gcitypes.pdf

21. United Nations, Department of Economic and Social Affairs, Population Division (2018). The World's Cities in 2018-Data Booklet (ST/ESA/ SER.A/417). Retrieved from: https://www.un.org/en/events/citiesday/assets /pdf/the_worlds_cities_in_2018_data_booklet.pdf

22. Wood J. (2019). This is the best city in the world for start-ups. World Economic Forum. Retrieved from: https://www.weforum.org/agenda/2019/11/ innovation-cities-technology-startups/ 